\section{Kolaborasi Petani Organik Lokal Sebagai Bentuk Ketahanan Pangan}

\author{
Rizky Ardiansyah ${ }^{1)}$, Dziqry \\ Fadillah $^{2)}$, M Dian Hikmawan ${ }^{3}$ \\ 1) Fakultas Ilmu Sosial dan Ilmu Politik, \\ Universitas Sultan Ageng Tirtayasa \\ ,2) Fakultas Ilmu Sosial dan Ilmu Politik, \\ Universitas Sultan Ageng Tirtayasa \\ 3) Fakultas Ilmu Sosial dan Ilmu Politik, \\ Universitas Sultan Ageng Tirtayasa \\ *Korespondensi Penulis E-mail: \\ dian.hikmawan@untirta.ac.id
}

\begin{abstract}
Abstrak
Penelitian kali ini bertujuan untuk mengetahui bagaimana kerjasama atau kolaborasi yang dilakukan oleh restoran Serasa dan petani organik lokal dalam merubah stigma masyarakat tentang makanan yang dikonsumsinya bukan hanya berpengaruh terhadap diri sendiri tapi juga lingkungan sekitarnya. Penelitian ini menggunakan dua teori yaitu kolaborasi dari Scott London, dan teori pemberdayaan dari Jamasy. Kolaborasi ini dilakukan sejak tahun2015 dimana restoran Serasa pertama kali didirikan dan mulai bekerja sama dengan petani lokal, dan mulai memberdayakan petani lokal dengan cara membeli hasil panennya untuk memenuhi bahan baku dengan harga yang sudah dinegosiasikan terlebih dahulu agar tidak ada pihak yang dirugikan. Dalam misinya untuk merubah stigma masyarakat dalam mengkonsumsi sayur, Serasa juga berharap ada campur tangan pemerintah agar setidaknya mengkampanyekan konsumsi sayur. Ini akan berpengaruh terhadap kesehatan masyarakat dan kesejahteraan petani lokal.
\end{abstract}

Kata kunci: Politik Lingkungan, Petani Lokal, Restoran Serasa.

\section{Collaboration of Local Organic Farmers as a Form of Food Security}

\begin{abstract}
This research aims to find out how the collaboration or collaboration carried out by Serasa restaurants and local organic farmers in changing people's stigma about the food they consume not only affects themselves but also the surrounding environment. This research uses two theories namely collaboration from Scott London, and the empowerment theory from Jamasy. This collaboration was carried out since 2015 where Serasa restaurant was first established and started working with local farmers, and began to empower local farmers by buying their crops to meet raw materials at a price that was negotiated first so that no party was harmed. In its mission to change the community's stigma in consuming vegetables, Serasa also hopes that there will be government intervention to at least campaign for vegetable consumption. This will affect the health of the community and the welfare of local farmers.
\end{abstract}

Keywords: Environmental Politics, Local Farmers, Serasa Restaurants. 


\section{A. PENDAHULUAN}

Isu lingkungan dewasa ini menjadi hal yang hangat untuk dibicarakan. Terdapat banyak pergerakan pergerakan yang tujuan akhirnya yaitu sama - sama melindungi alam. Pada penelitian yang akan kami bahas ini kami berfokus pada restoran yang sangat menghargai lingkungan, yaitu restoran bernama "Serasa " . Restoran Serasa ini didirikan oleh anak muda bernama Fitriani Rahmah dan adiknya Eva Nurfadilah pada April 2015. Maksud dari didirikannya restoran ini adalah suatu gerakan sadar makan yang percaya bahwa apa yang kita makan akan berpengaruh terhadap kesehatan kita, kesejahteraan petani, dan kelestarian lingkungan. Sehingga ini akan membuat gaya hidup yang sehat, etis dan berkelanjutan. Serasa adalah bisnis lokal yang berbasis di Bandung,Jakarta, dan Bekasi berkomitmen untuk menyediakan makanan pertanian ke meja melalui pengalaman salad yang lezat dengan saus buatan sendiri.

Serasa didirikan bukan hanya sekedar bisnis lokal saja, tapi terdapat alasan lain untuk mendirikan restoran ini. Restoran ini didirikan oleh Fitri dan Eva sebagai implementasi dari rasa sedihnya karena ditinggalkan oleh ayahnya karena penyakit kanker. Dengan didirikannya Serasa ini, bukan hanya sekedar bisnis pada umumnya tapi juga diharapkan agar bisa merubah stigma masyarakat bahwa makanan yang dikonsumsi harus selalu diperhatikan dan tidak sembarangan, agar kesehatan juga tetap terjaga.
Serasa menciptakan menu yang sehat dari bahan baku yang segar dan berasal dari petaniorganik lokal. Dengan begitu Serasa juga membantu untuk memberdayakan petani lokal dengan cara bekerja sama dengan petani lokal tersebut untuk memenuhi kebutuhan bahan baku dari restoran Serasa itu sendiri.

Serasa yang berarti "satu" rasa terlahir karena hasrat dan tujuan untuk mendorong orang makan lebih banyak sayuran. Serasa percaya bahwa mengubah kebiasaan makan dengan kebiasaan yang lebih baik melalui banyak salad adalah pilihan untuk hidup yang lebih sehat. Adapun misi dari didirikannya Serasa ini adalah membuat makanan yang sehat, lezat, menyenangkan, nyaman, dan dapat diakses oleh semua orang sambil memberdayakan petani lokal melalui penyediaan bahan baku di restoran Serasa sendiri. Serasa juga dalam Instagramnya berisikan konten untuk mengajak beralih ke pola makan nabati yang ramah lingkungan.

Pada penelitian ini kami akan merumuskan masalah yaitu bagaimana kolaborasi antara restoran Serasa dengan petani lokal organik. Khususnya tentang bagaimana negosiasi yang terjadi antara kedua pihak ini, sehingga Serasa dan petani lokal dapat bekerja sama tidak hanya sebatas rekan bisnis, tapi juga terdapat aksi sosial didalamnya yaitu, samasama melindungi alam dengan cara merubah pemikiran tentang makanan. 


\section{B. TEORI (Literature Review)}

Pada zaman milenial ini berbagai cara harus didapati agar mendapatkan sebuah hasil yang menguntungkan, pada bidang bisnis juga harus bisa menciptakan sebuah mahakarya bukan hanya untuk diri sendiri akan tetapi menguntungkan untuk masyarakat luas, pada jurnal ini yang membahas sebuah kolaborasi antara pengusaha maknanan vegetarian dengan petani organic local, yang terdapat sebuah kerjasama untuk menciptakan kesadaran masyarakat untuk mengkonsumsi makanan sehat seperti sayur dan buah, juga guna membantu perekonomian petani organi local sekitar.

Kolaborasi merupakan istilah umum yang sering digunakan dalam menggambarkan sebuah pola hubungan kerja sama yang dilakukan lebih dari satu pihak. Ada banyak pula pengertian tentang kolaborasi yang dikemukakan oleh ahli dengan sudut pandang yang berbeda. Untuk mendefenisikan secara utuh dan menyeluruh konsep kolaborasi tidaklah mudah. Namun secara umum kolaborasi adalah hubungan antara organisasi yang saling berpartisipasi dan saling menyetujui untuk Bersama mencapai tujuan (Hikmawan, 2017)h, berbagai informasi, berbagai sumberdaya, berbagai manfaat, dan bertanggungjawab dalam pengambilan keputusan Bersama untuk menyelesaikan sebuah perkara masalah.

Kolaborasi selain kerjasama antar organisasi harus mendapatkan sebuah timbal balik yang positif atau keuntungan untuk dua belah pihak dengan jangka waktu yang tidak ditentukan selama itu masih saling ketergantungan dan memungkinkan sebuah urusan tetap.

Berarti kolaborasi itu sendiri tidak dibatasi oleh waktu atau periode tertentu, selama masih ada urusan yang memiliki singgungan atau irisan dengan pihak lain maka kolaborasi masih tetap diperlukan. Kolaborasi melibatkan beberapa pihak ,mulai dari tingkat individu, kelompok kerja, dan organisasi. Dalam menjalankan kolaborasi sangat penting untuk memahami kinerja Lembaga publik. Maka kolaborasi tidaklah memiliki tenggang waktu batas jadi selama kedua belahpihak masih membutuhkan dan saling beririsan maka kolaborasi itu akan tetap ada, itu yang membedakan kolaborasi dan kerja sama karena kolaborasi merupakan interaksi di antara beberapa orang yang terus berkesinambungan.

$$
\text { Pada hekekatnya tujuan }
$$

kolaborasi itu sendiri adalah untuk mencapai tujuan Bersama saling membantu antara satu dengan yang lainnya. hal ini sebagaimana yang dikemukakan oleh Abdulsyani, kolaborasi adalah suatu bentuk proses social, dimana didalamnya terdapat aktivitas tertentu yang ditujukan untuk mencapai tujuan Bersama dengan saling membantu dan saling memahami aktivitas masing-masing (Hikmawan \& Hidayat, 2016).

Hal ini seperti pembahasan pada kelompok kami, dimana perusahaan makanan vegetarian yang 
berkolaborasi dengan petani organic local demi mencapai tujuan Bersama yaitu pihak restoran menginginkan kesadaran masyarakat akan kesehatan dalam memilih sebuah makanan sehat, dan petani organic local tidak secara langsung ikut di promosikan dan mensejahterakan para petan organic lokal itu sendiri.

Kolaborasi antara kedua belah pihak seperti serasa dan petani local membuat kelompok kami menggunakan teori scott London yang dimana kedua belah pihak saling beririsan dalam urusannya masingmasing dan mendapatkan keuntungan yang diperoleh dari hasil irisan atau kerja sama antara kedua belah pihak. Serasa menjalin kerja sama dengan petani local karena rasa kekhawatirannya dengan kesadaran masyarakat banyak tentang pola hidup sehat mengingat kesedihan ketika ditinggalkan ayahanda karena penyakit jantung yang diderita akibat pola makan tidak sehat. Serasa menyadari dengan makanan pola sehat akan menyelamatkan banyak hewani dan lebih banyak mengkonsumsi sayursayuran berguna juga untuk kesejahteraan para petani organic local disana.

Serasa menjadi salah satu pioneer dalam menerapkan pola hidup sehat sadar akan makanan yang dikonsumsi akan memengaruhi ekosistem yang ada dan tetap menjaga kelestarian hewanihewani serta kesehatan bagi masyarakat. Restauran Serasa berupaya semaksimal mungkin untuk menjaga lingkungan kelestarian alan dengan menjaga ekosistemnya juga akan kesehatan bagi tubuh. Peran petani local yang memberdayakan sayuran-sayuran organi yang seha dan terjaga dari bakteri membuat makanan atau prodak dari restorant Serasa menjadi lebih sehat dan pemberdayaan dari petani local pun dilakukan dengan baik dan bertanggung jawab sehingga petani local bisa memberdayakan secara mandiri hasil dari panennya. Jamasy (2004) mengemukakan bahwa konsekuensi dan tanggung jawab utama dalam program pembangunan melalui pendekatak pemberdayaan adalah masyarakat berdaya atau memiliki daya kekuatan atau kemampuan. Kekuatan yang dimaksud dapat dilihat dari aspek fisik dan material, ekonomi, kelembagaan, kerja sama, kekuatan intelektual dan komitmen bersama dalam menerapkan prinsip-prinsip pemberdayaan. Kemampuan berdaya mempunyai arti yang sama dengan kemandirian masyarakat (Hikmawan, 2014). Salah satu cara untuk meraihnya adalah dengan membuka kesempatan bagi seluruh komponen masyarakat dalam tahapan program pembangunan. Setiap komponen masyarakat selalu memiliki kemampuan atau berpotensi. Keutuhan potensi ini akan dapat dilihat apabila di antara mereka mengintegrasikan diri dan bekerja sama untuk dapat berdaya dan mandiri.

Pada hakikatnya pemberdayaan adalah suatu proses dan upaya untuk memperoleh atau memberikan daya, kekuatan atau kemampuan kepada individu dan masyarakat lemah agar dapat mengidentifikasi, menganalisis, menetapkan kebutuhan dan potensi 
serta masalah yang dihadapi dan sekaligus memilih alternative pemecahannya dengan mengoptimalkan sumber daya dan potensi yang dimiliki secara mandiri (Hikmawan, 2017). Teori pemberdayaan dari jamasy sangat jelas menurut kelompok kami memiliki pendekatan yang sama disatu sisi scott London memperlihatkan bagaimana sebuah kolaborasi terjadi karena adanya irisan dari kedua belah pihak yang akan menguntungkan keduanya. Secara garis besar Scott London mendefinisikan tentang kolaborasi itu sendiri lain pihak seperti Jamasy membahas tentang bagaimana sebuah pemberdayaan sebuah kelompok oleh satu pihak agar menjadi mandiri dan memanfaatkan apa yang ada sehingga menjadi sebuah ladang usaha bagi mereka sendiri dan bertanggung jawab.

Kelompok kami memakai teori Scott London dan Jamasy sudah di telaah dengan seksama karenanya kedua teori bersinggungan satu sama lain terhadap judul yang kami bawa kan tentang kolaborasi antara restoran serasa dengan petani local yang dimana restoral selain berkolaborasi dengan petani local guna menghidangkan masakan vegetarian yang sehat serta melestarikan hewan dan lingkungan sekitarnya adapun petani yang terbantu perekonomian dengan adanya kolborasi ini dan teori Jamsy memaparkan sebuah pemberdayaan yang dimana individua tau kelompok mengajarkan individua tau kelompok lain dengan maksud tujuan agar pemberian daya atau kekuatan atau sebuah ilmu yang dimana akan menjadi suatu progress yang berkembang dan bisa membuka lahan usaha dengan mandiri dan bertanggung jawab. Petani local terbantu dengan restoran serasa, mereka pun tidak hanya mengajak untuk berkolaborasi untuk mencapai keuntungan, edukasi pun di berikan kepada petan petani local agar tetap berkembang dan berusaha agar mempunyai daya saing kuat dan juga edukasi untuk pemasaran bahan hasil panen sayuran agar bisa dikembangkan lagi. Terjalinnya kolaborasi dan pemberdayaan didalam sebuah tema yang kami angkat adalah petani local beririsan dan menjalin kerja sama oleh restoran serasa dengan terciptanya kerjasama dan sebuah pemberdayaan, restoran serasa membuat petani local tidak kehilangan perekonomiannya.

Restoran Serasa membuat masyarakat petani local mempunyai penghasilan dan sebuah pengetahuan dimana hasil panen akan lebih berguna dan memiliki nilai ekonomi yang lebih besar. Teori Scott London dan Jamasy sudah pas menurut kelompok kami karena kelompok dan pengusaha beririsan untuk menjalin kerja sama dan pemberdayaan petani local disana.

\section{METODE}

Penelitian menggunakan pendekatan kualitatif dengan tipe penelitian studi kasus. Penelitian berfokus pada model kolaborasi pengusaha makanan vegetarian dan petani local, hambatan dan manfaat bagi masyarakat petani organic local dari adanya pengusaha atau restoran 
makanan vegetarian. Data penelitian diperoleh dari sumber primer yaitu penelitian lapangan dengan melakukan wawancara dengan beberapa informan yaitu owner dari pengusaha makanan vegetarian dan, petani organic local setempat, data juga diperoleh dari observasi lapangan terutama melihat pemanfaatan petani organic local. Data sekunder diperoleh dari dokumentasi. Data penelitian dianalisis secara deskriptif kualitatif dengan cara analisis konteks dari tinjauan pustaka dan Analisa dari pernyataan wawancara informan.

\section{HASIL DAN PEMBAHASAN}

Isu lingkungan belakangan ini sedang ramai dibicarakan, ada banyak gerakan dan organisasi - organisasi yang membawa isu tentang lingkungan. Penyebab dari lahirnya gerakan dan organisasi lingkungan ini adalah pemanasan global yang tak lain disebabkan oleh manusia sendiri. Maka ketika manusia mulai merasakan perbedaan di bumi seperti suhu udara yang semakin panas, dan mulai mencairnya es di kutub, lalu manusia mulai sadar bahwa alam butuh perhatian lebih. Akhirnya lahirlah kesadaran untuk bergerak memperbaiki, dan meminimalisir kerusakan di bumi ini. Ada banyak cara untuk melindungi bumi, salah satunya yaitu yang dilakukan oleh restoran Serasa. Serasa adalah restoran dengan menu berbagai macam salad. Restoran Serasa ini didirikan oleh anak muda bernama Fitriani Rahmah dan adiknya Eva Nurfadilah pada April 2015. Maksud dari didirikannya restoran ini adalah suatu gerakan sadar makan yang percaya bahwa apa yang kita makan akan berpengaruh terhadap kesehatan kita, kesejahteraan hewan dan petani, dan kelestarian lingkungan. Sehingga ini akan membuat gaya hidup yang sehat, etis dan berkelanjutan. Serasa adalah bisnis lokal yang berbasis di bandung, jakarta, dan bekasi berkomitmen untuk menyediakan makanan pertanian ke meja melalui pengalaman salad yang lezat dengan saus buatan sendiri.

Berdirinya restoran ini bukan hanya sekedar untuk bisnis, tapi juga sebagai gerakan untuk merubah pola pikir masyarakat mengenai makanan. Makanan yang dikonsumsi oleh masyarakat akan berdampak panjang untuk hidupnya, seperti kesehatan di masa tua dan kebermanfaatan untuk para petani lokal.Serasa yang berarti "satu" rasa terlahir karena hasrat dan tujuan untuk mendorong masyarakat untuk mengkonsumsi lebih banyak sayuran. Serasa percaya bahwa mengubah kebiasaan makan dengan kebiasaan yang lebih baik melalui salad adalah pilihan untuk hidup yang lebih sehat. Adapun misi didirikannya Serasa ini adalah membuat makanan yang sehat, lezat, menyenangkan, nyaman, dan dapat diakses oleh semua orang sambil memberdayakan petani lokal melalui penyediaan bahan baku di restoran Serasa sendiri. Serasa juga dalam Instagramnya berisikan konten untuk mengajak agar beralih ke pola makan nabati yang ramah lingkungan. Ada yang menarik dari restoran Serasa yaitu salah satu alasan mengapa restoran ini didirikan adalah atas 
implementasi rasa sedih dari KakaAdik Fitri dan Eva atas kepergian ayahnya karena penyakit kanker yang diderita. Itu menjadi salah satu semangat yang mendorong berdirinya Serasa ini. Salah satu alasan lain Serasa ini didirikan adalah karena Fitri dan Eva sendiri suka mengkonsumsi sayuran dan olahan dari sayur, dan dengan pengalaman traveling nya ke berbagai daerah mendatangkan inspirasi untuk mendirikan Serasa itu sendiri. Dengan pengalamannya, akhirnya Fitriani dan Eva membuat olahan dari sayur yang disukai banyak orang. Tujuan awal sampai saat ini untuk Serasa sendiri ialah mendorong masyarakat untuk mengkonsumsi sayur, dan memanfaatkan sayuran dari hasil panen petani lokal langsung.

Tahun pertama didirikannya Serasa, lebih berfokus untuk mencari branding image dari Serasa, salah satunya dengan cara aktif di komunitas sehat yang ada di Bandung. Melakukan sosialisasi-sosialisasi ke sekolah, memberi pengetahuan kepada siswa tentang healthy food dan praktik untuk membuat healthy food. Itu dilakukan untuk mencapai tujuan dari Serasa ini sendiri yaitu mendorong masyarakat untuk mengkonsumsi sayur lebih banyak, karena ada sebagian pandangan masyarakat yang masih menganggap bahwa memakan sayur adalah hal yang sulit. Padahal sayuran itu sendiri bisa kita olah menjadi salad yang proses pembuatannya lebih mudah dan praktis. Sehingga bisa merubah eating habbit masyarakat kearah yang lebih baik, dan menciptakan generasi sehat yang berkesinambungan. Setalah semakin berkembang, akhirnya Serasa membuka kelasnya sendiri untuk sosialisasi ke masyarakat yang diadakan setiap 3-4 bulan sekali.

Awal mula memulai bisnis ini, Serasa memilih untuk menggunakan sistem pre-order karena produk yang dijual adalah produk yang masih sangat segar. Pada tahun kedua barulah Serasa membuka restoran salad di Bandung. Penjualan produknya dilakukan secara online dan offline. Serasa menyediakan juga menu dengan jumlah yang besar, biasanya untuk kantor ataupun sekolah-sekolah yang sedang mengadakan event. Pada tahun 2020, khususnya diawal maret penjualan produk Serasa banyak dilakukan secara online ditambah dengan isu pandemi Corona (Covid-19) membuat penjualan secara online lebih banyak dipilih oleh masyarakat. Target pasaran produk Serasa ini adalah masyarakat yang rata-rata berusia 2535 tahun, khususnya adalah ibu-ibu muda yang mobilitasnya sudah cukup tinggi dan mulai sadar tentang healthy food. Jadi mereka memilih produk Serasa untuk makan siang di kantor.

Untuk bahan baku yang dipilih oleh serasa khususnya untuk fresh product, hampir $90 \%$ bahannya diperoleh dari petani lokal, dan ada beberapa bahan yang tidak bisa dipenuhi langsung dari petani lokal dan harus memilih warung konvensional. Serasa bekerja sama dengan petani organic lokal yang berlokasi di Parompong, Ciwidey, dan lembang, Serasa juga bekerja sama dengan petani hidroponik yang 
berlokasi di Padalarang. Memilih petani lokal untuk diajak bekerja sama, Serasa biasanya datang langsung memeriksa lahan petani tersebut untuk memastikan bahwa sayur yang dihasilkan adalah sayur organik. Tiga petani organik lokal dan satu petani hidroponik itulah yang kini menjadi sumber bahan baku restoran Serasa di Tiga cabang, antara lain, Bandung, Jakarta, dan Bekasi. Serasa memilih petani lokal karena kesegaran dari sayuran lebih terjamin dan terhindar dari bahan pengawet. Jadi bahan baku untuk memenuhi kebutuhan di restoran Serasa ini berasal dari sayuran yang segar dari petani lokal. Selain itu, kita bisa melihat sisi manusiawi dari pihak Serasa karena telah memberdayakan petani dengan cara membeli hasil panennya tersebut.

Serasa membantu petani lokal menjamin hasil panennya akan terjual melalui kerja samanya dengan petani tersebut. Jadi jika dibandingkan dengan menjual hasil panennnya ke supermarket dengan syarat kualitas yang tinggi dalam arti tidak boleh ada cacat sedikit pun, dan jika dibandingkan dengan menjualnya ke distributor dengan harga yang bisa dipangkas menjadi lebih murah dari harga pasaran, petani lokal bisa memilih menjual hasil panennya ke Serasa. Keuntungan sendiri dari petani ketika menjual hasil panennya ke Serasa adalah negosiasi yang dilakukan antara kedua pihak tidak akan merugikan satu sama lain, jadi petani juga bisa menjual barangnya dengan harga dipasaran. Selain itu, untuk standar kualitas yang diinginkan oleh
Serasa tidak setinggi supermarket, Serasa masih bisa menerima hasil panen yang terdapat sedikit defect selama masih layak untuk dikonsumsi.

Salah satu hambatan untuk bekerja sama dengan petani adalah ada sebagian petani yang menjual hasil panennya ke distributor, dan dengan harga yang lebih murah. Salah satu faktornya adalah petani kurang mampu membaca kondisi pasar untuk hasil panen mereka. Jadi mereka akan bergantung kepada distributor. Untuk menghindari hal tersebut terjadi, petani harus menambah kapabilitasnya, seperti bisa membaca bagaimana trend di pasar. Serasa sendiri belum melakukan edukasi seperti itu ke petani, hanya sebatas membeli langsung dari petani, tapi serasa lebih focus mengedukasi konsumennya agar lebih paham mengenai healthy food dan membeli bahan lokal yang banyak dijual di pasar konvensional atau bahkan ke petani lokal langsung.

Hambatan lain yang dirasakan oleh Serasa sendiri adalah ketika petani gagal panen dan tidak bisa memenuhi permintaan dari serasa, dan juga kualitas panen yang kurang bagus dan tidak bisa digunakan. Itu menjadi tantangan bagi petani agar meminimalisir gagal panen dan mempertahankan kualitas hasil panennya tersebut. Untuk permasalahan harga, pihak Serasa dan petani selalu berkomunikasi ketika terjadi ketidaksesuaian harga, misalnya ketika petani meminta agar harga naik karena modal untuk cocok tanam juga naik, Serasa akan melakukan negosiasi dan ketika 
harganya masih bisa diterima, itu tidak menjadi masalah untuk Serasa. Akhirnya barang yang dibeli di pasar dan barang yang dibeli di petani langsung harganya tidak jauh beda, hanya ketika Serasa membeli barang langsung di petani lokal dengan harga yang tidak jauh beda dengan harga di pasar berarti uangnya langsung masuk ke kantong petani lokal. Beda halnya ketika barang di pasar yang sudah melalui distributor sehingga keuntungan petani lebih kecil. Ini adalah salah satu hal yang dilakukan Serasa untuk memberdayakan petani lokal.

Serasa sudah memiliki tiga cabang diantaranya terletak di Bandung, Jakarta, dan Bekasi. Dari ketiga cabang tersebut untuk pemenuhan kebutuhan bahan bakunya berasal dari petani lokal. Serasa yang dari awalnya hanya berjualan dengan system pre order dan delivey order di Bandung serta masih belum memiliki karyawan, secara bertahap menjadi restoran yang diminati banyak orang, sampai akhirnya bisa membuka cabang di tiga kota. Dalam proses membuka cabang yang baru, Serasa tidak serta merta langsung menentukan dimana letak cabang tersebut. Serasa melakukan survey terlebih dahulu, biasanya melalui media social dan research tentang laporan wilayah setempat sampai benar-benar yakin bahwa konsumennya itu ada. Ini juga akan berpengaruh terhadap kesegaran (kualitas) bahan baku, karena ketika Serasa membuka cabang ditempat yang demands nya kurang, maka bahan baku akan lebih lama habis, sehingga kesegaran bahan baku akan menurun. Lebih baik ketika mengetahui permintaannya sudah banyak dan stabil dan mewadahi konsumen tersebut, lalu barulah membuka cabang, dibandingkan harus membuka cabang dan memaksakan agar merubah stigma masyarakat untuk menambah konsumsi sayur. Jadi selain terdapat nilai social, Serasa juga menjadi bisnis yang sehat. Selain itu, hal yang harus diperhatikan ketika akan membuka cabang yang baru adalah bagaimana akses ke sayuran yang berasal dari petani lokal sendiri. Sehingga lingkarang keberpengaruhan satu sama lain antara Serasa, konsumen (permintaan) dan petani lokal tetap berjalan dengan baik. Serasa tidak bisa memaksakan ketika akses untuk memperoleh bahan baku dari petani lokal sangatlah sulit. Semakin dekat akses terhadap bahan baku dan mengetahui dari mana berasalnya, semakin sehat dan terjamin pula bahan baku yang didapatkan. Dibandingkan dengan memilih bahan baku (sayur) secara impor, kita tidak tahu bahwa bahan baku tersebut mungkin sudah terkontaminasi oleh bahan atau zat yang lain.

Selanjutnya membahas tentang harapan dari Serasa. Yang pertama, harapan untuk petani lokal, semoga petani bisa lebih cerdas dalam memperhitungkan hasil panennya, dan juga melihat kondisi pasar agar tidak terpaku kepada distributor. Yang kedua, harapan untuk masyarakat agar lebih sadar atas makanan yang dikonsumsi bukan hanya bermanfaat 
untuk diri sendiri tapi juga harus bermanfaat untuk lingkungan seperti petani lokal. Masyarakat juga diharapkan sadar bahwa mengkonsumsi sayur adalah hal yang penting dan mudah, terlebih sayur tersebut berasal dari petani lokal. Yang terakhir adalah harapan untuk pemerintah, Serasa berharap agar pemerintah mendukung produk lokal dan setidaknya membuat kampanye agar menghmbau masyarakat untuk mengkonsumsi sayur. Dengan begitu pemerintah membantu mensejahterakan petani, dan memperbaiki kualitas kesehatan masyarakat.

\section{E. SIMPULAN DAN SARAN}

Kesimpulan dari jurnal kami yang berjudul kolaborasi restoran serasa dengan petani organik lokal untuk menciptakan makanan yang ramah lingkungan, diawali dengan rasa kehilangan yang mendalam, karena ditinggalkan oleh sang ayahanda yang telah berpulang kehadapan Tuhan. Ayahanda dari fitri dan eva memiliki penyakit kanker dan tidak tertolong, kedua bersaudari itu akhirnya menyimpulkan untuk menciptakan suatu makanan yang sehat serta ramah lingkungan. Dari kesedihan itulah mereka mendirikan restoran serasa yang dimana menu makanan di restoran tersebut semua terbuat dari sayur-sayuran karena ingin menciptakan pola hidup sehat. Tidak hanya pola hidup sehat yang mereka gagaskan, meningkatkan kesadaran bagi masyarakat juga adalah salah satu prioritas yang digagaskan oleh mereka berdua sehingga masyarakat setelah mengetahui bagaimana penerapan pola hidup sehat dan menyadari betapa bahayanya mengkonsumsi junkfood dan fastfood yang bisa merusak kesehatan. Menerapkan pola makan sehat dan merangsang kesadaran masyarakat akan pentingnya pengaruh makanan yang dikonsumsi, restoran serasa juga ikut andil dalam memberdayakan petani local dengan membeli hasil panennya. Sehingga serasa menjadikan petani local sebagai supplier dari kebutuhan bahan baku di tiga cabang restoran Serasa dan membantu perekonomian petani organic lokal tersebut. Ada tiga aktor yang terlibat dalam tulisan ini diantaranya, Serasa, petani lokal, dan konsumen. Serasa membeli langsung dari petani lokal bukan hanya untuk pemenuhan kebutuhan bahan baku saja, tetapi untuk menjamin hasil panen petani lokal tersebut. Serasa mengedukasi konsumen agar lebih banyak mengkonsumsi sayur dan membelinya dari petani lokal karena kualitasnya lebih terjamin dibandingkan dengan sayuran impor. Jadi dari ketiga aktor ini terjadi saling keterkaitan satu sama lain, dan saling menguntungkan.

\section{DAFTAR PUSTAKA}

Azahari, A., 2000. Kemitraan Agribisnis Tiga Tungku. Journal of Indonesian Economy and Business, 15(2), pp.186-200.

Hikmawan, M. D. (2014). Politik Perbedaan: Demokrasi dalam Paradoks. Universitas Gdjah Mada. 
Hikmawan, M. D. (2017). Politik Perbedaan: Minnoritas dalam Implementasi Kebijakan. Journal of Indonesian Public Administration and Governance Studies (JIPAGS), 1(1), 88-98.

Hikmawan, M. D., \& Hidayat, R. (2016). Depoliticisation of Public Issue: Low Degree of Government ' $S$ Democratic Legitimacy. Journal of Governance, 1(1), 23-37. https://doi.org/http://dx.doi.org/ 10.31506/jog.v1i1.1311

Riskasari, Tahir Nurbiyah. 2018. Kolaborasi Aktor Pembangunan dalam Mewujudkan Desa Mandiri di Desa Bongki Lengkese Kabupaten Sinjai. Jurnal Administrasi Publik. 8(2). Hal 121126.

Rokhayah, S., Amalia, W. R., Rahmawati, I. R., Zhamroni, A., \& Pratiwi, D. (2019). Pemberdayaan Karang Taruna Melalui Pemanfaatan Limbah Kaos Kaki Di Desa Mojo Kecamatan Beringin Kabupaten Ngawi. Adimas: Jurnal Pengabdian Kepada Masyarakat, 3(2), 36-42.

Saputra, B. (2018). Implementasi Pemberdayaan Masyarakat Melalui Program Corporate Social Responsibility Konservasi Kawasan Laut Badak Di Kota Bontang.

Sari, B.Y. and Heryanto, M.A., 2018. Studi Komparasi Pendapatan Petani Lokal dengan Petani Modern Padi Sawah di Desa Mekarjaya, Kecamatan Kiarapedes, Kabupaten Purwakarta. Jurnal Ilmiah Mahasiswa Agroinfo Galuh, 4(3), pp.920-926.
Scott London, Collaboration and Community, di unduh dari http://www.scottlondon.com/rep orts/collaboration.pdfpada tanggal 31 Mei 2020 , h. 2.

Thio, S., 2012. Persepsi Konsumen Terhadap Makanan Organik di Surabaya. Jurnal Manajemen Perhotelan, 4(1), pp.18-27. 